\title{
Evaluation of Pilot-Scale Melter Systems for the Direct Vitrification Development Program
}

\author{
C. W. McCray
}

T. D. Thomson

September 2001 


\title{
Evaluation of Pilot-Scale Melter Systems for the Direct Vitrification Development Program
}

\author{
C. W. McCray, INEEL \\ T. D. Thomson, SAIC \\ September 2001 \\ Idaho National Engineering and Environmental Laboratory \\ Idaho Falls, Idaho 83415 \\ Prepared for the \\ U.S. Department of Energy \\ Assistant Secretary for Environmental Management \\ Under DOE Idaho Operations Office \\ Contract DE-AC07-99ID13727
}




\section{EXECUTIVE SUMMARY}

This report documents the results of an evaluation conducted to identify a joule-heated melter system that could be installed in the Idaho Falls area in support of the Direct Vitrification Development Program. The relocation was to be completed by January 1, 2002, within a total budget of one million dollars. Coordination with the Department of Energy Tanks Focus Area identified five melters or melter systems that could potentially support the Direct Vitrification Development Program. Each unit was inspected and evaluated based on qualitative criteria such as availability, completeness of the system, contamination, scalability, materials of construction, facility requirements, and any unique features.

The SVS-III, built as a 1/7 scale model (based on surface area of the melt, 1/14 scale based on volume) of the Vitrification Facility at the West Valley Demonstration Project, was selected as most suitable for the Direct Vitrification Development Program. Key features are:

- It has been fully tested as an integrated system under flowsheet conditions similar to those targeted for SBW surrogate testing.

- It will not require any decontamination efforts, and the refractory is new. System Operability testing of the system could be initiated immediately after transport and assembly in the selected facility.

- $\mathrm{NO}_{\mathrm{x}}$ abatement during initial testing would be accomplished with the existing selective catalytic reduction system, which is included. Future development of alternative $\mathrm{NO}_{\mathrm{x}}$ abatement systems would not require major modification to the off-gas system, but rather a relatively simple disconnect of the selective catalytic reduction system and tie-in to the new $\mathrm{NO}_{\mathrm{x}}$ abatement system.

- The feed preparation and delivery system is much more complete than any of the other candidate systems. It includes both liquid and dry bulk delivery systems to the makeup tank, in line grinders to prevent line plugging and pump damage due to transfer of large particles, and continuous recirculation loops to maintain homogeneity of the feed slurry.

Funding for the relocation is not currently available, and there are no plans in place to pursue obtaining the melter. 


\section{CONTENTS}

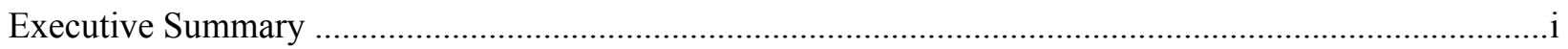

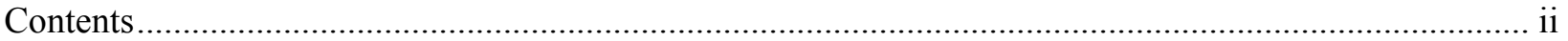

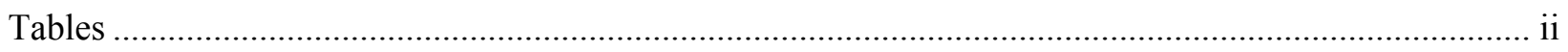

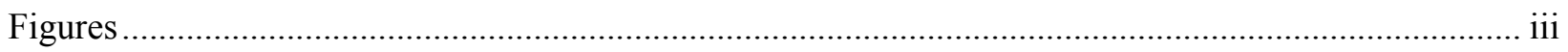

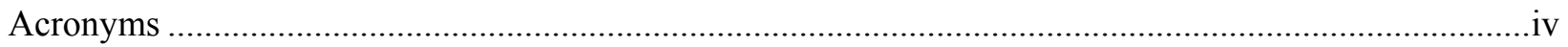

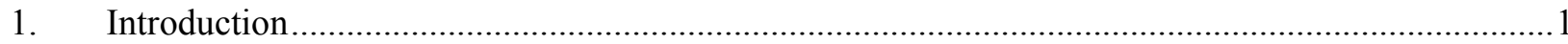

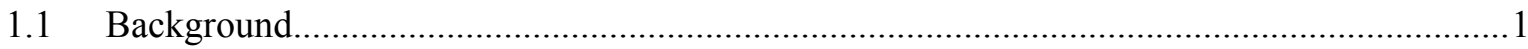

1.2 Direct Vitrification Development Activities - Program Requirements.................................2

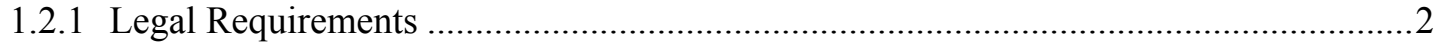

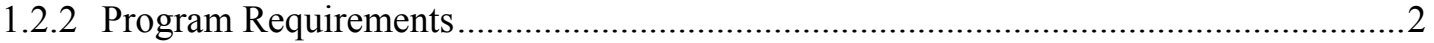

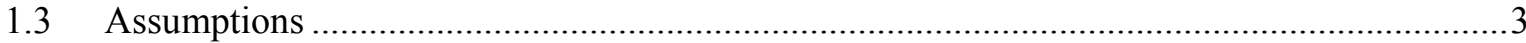

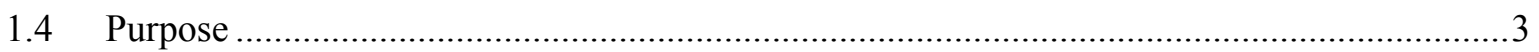

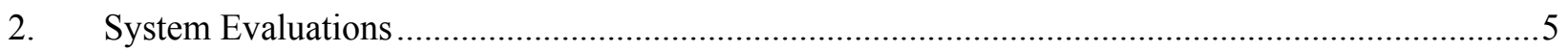

2.1 Scaled Vitrification System, West Valley Demonstration Project .......................................5

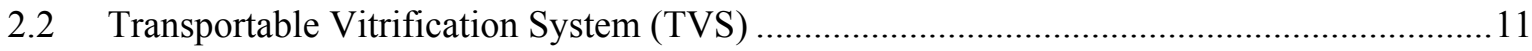

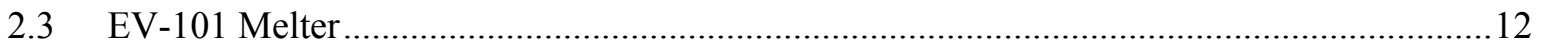

2.4 Tenth- scale Defense Waste Processing Facility Melter ................................................. 14

2.5 Engineering Scale (German) Melter ............................................................................ 15

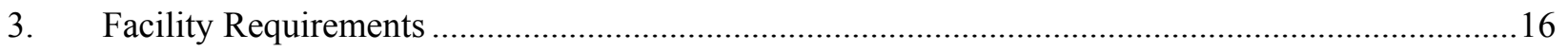

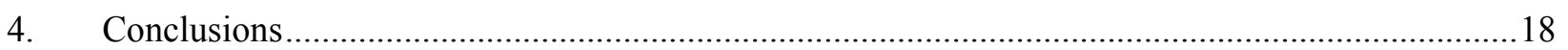

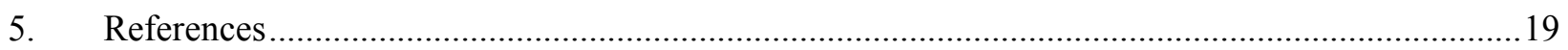

\section{TABLES}

Table 1. Key Criteria Evaluation of Melter Systems. 


\section{FIGURES}

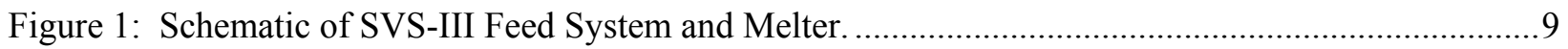

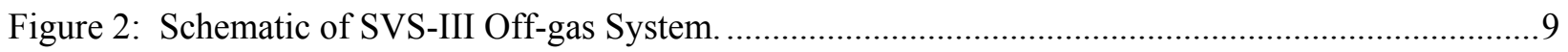

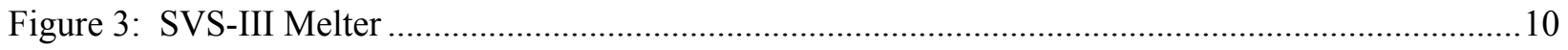

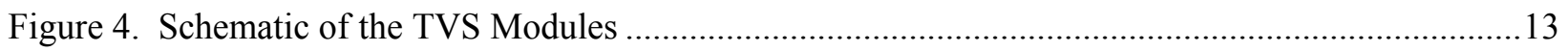

Figure 5: Melter similar to 1/10 scale DWPF and Engineering Scale Melter (Grunewald 1993).............15 


\section{ACRONYMS}

\begin{tabular}{|c|c|}
\hline BBWI & Bechtel BWXT Idaho, LLC \\
\hline DOE & United States Department of Energy \\
\hline DWPF & Defense Waste Processing Facility \\
\hline ES\&H & Environmental, Safety, and Health \\
\hline ESM & Engineering Scale Melter \\
\hline FHT & Feed Hold Tank \\
\hline HEME & High Efficiency Mist Eliminator \\
\hline HLW & High-Level Waste \\
\hline INEEL & Idaho National Engineering and Environmental Laboratory \\
\hline INTEC & Idaho Nuclear Technology and Engineering Center \\
\hline MFT & Melter Feed Tank \\
\hline PTS & Pneumatic Transport System \\
\hline QSL & Qualified Suppliers List \\
\hline RCRA & Resource Conservation Recovery Act \\
\hline SBW & Sodium Bearing Waste \\
\hline SCR & Silicon Controlled Rectifier \\
\hline SMT & Slurry Mix Tank \\
\hline SVS & Scaled Vitrification System \\
\hline TECO & Toledo Engineering Company \\
\hline TVS & Transportable Vitrification Facility \\
\hline VF & Vitrification Facility \\
\hline WVDP & West Valley Demonstration Project \\
\hline
\end{tabular}




\section{INTRODUCTION}

Since 1963, irradiated nuclear fuels have been reprocessed at the Idaho Nuclear Technology and Engineering Center (INTEC), formerly the Idaho Chemical Processing Plant. The resulting acidic high-level liquid radioactive waste (HLW) was solidified into a high-level waste calcine and stored in stainless steel bins enclosed in concrete vaults.

In April, 1992, the United States Department of Energy (DOE) announced that spent fuel would no longer be reprocessed to recover enriched uranium and called for a shutdown of the reprocessing facilities. Since that time, high-level waste has not been generated. The inventory of liquid HLW has been calcined and is stored at the calcined solids storage facilities at INTEC. Residual radioactive sodium bearing waste (SBW) is stored in stainless-steel tanks contained in concrete vaults at the INTEC Tank Farm Facility.

About 997,000 gallons $\left(3,775 \mathrm{~m}^{3}\right)$ of SBW, which was produced during decontamination and other incidental plant operations, remains in the Tank Farm Facility as of August 2001. An additional $4386 \mathrm{~m}^{3}$ of calcined solids is currently in storage. Both of these wastes must be treated to comply with the 1995 Settlement Agreement amongst the DOE, the US Navy, and the State of Idaho (DOE 1995).

The stabilization and disposal of mixed wastes, wastes that contain both hazardous and radioactive materials, is a significant waste management challenge to the DOE. Vitrification, which can convert a variety of wastes, including the SBW and calcine, into highly durable glass is being evaluated for ultimate treatment to meet DOE commitments. Past laboratory and smallscale melter testing has proven the applicability of vitrification technologies for the treatment of these INTEC wastes (Vienna et al. 1999a, Vienna et al. 1999b, Musick 2000). Integrated testing in scalable pilot facilities is now desired, and available equipment that could potentially be used at the INEEL is evaluated in this report.

\subsection{Background}

On September 29, 2000, BBWI's HLW Program was instructed by the DOE to redirect their SBW programs from a Cesium Ion Exchange baseline to Direct Vitrification as a result of the anticipated HLW Environmental Impact Statement Record of Decision (Dirkmaat 2000). During fiscal year 2001 direct vitrification development activities were concentrated on treating the inventory of SBW currently stored at the INTEC Tank Farm Facility. After treating SBW, the focus would shift to the calcine stored in the INTEC bin sets.

The U.S Environmental Protection Agency has identified vitrification as the best demonstrated available technology for immobilization of wastes generated during the reprocessing of nuclear fuel (EPA 2000). The joule-heated melter is used to vitrify high-level radioactive waste at the Savannah River Defense Waste Processing Facility and the West Valley Vitrification Facility, and is the baseline technology for the Hanford Waste Vitrification Plant. The technology has been deployed internationally and operated remotely since 1985 at the PAMELA plant in Mol, Belgium. 


\subsection{Direct Vitrification Development Activities - Program Requirements}

\subsubsection{Legal Requirements}

The 1995 Settlement Agreement, hereafter referred to as the "Settlement Agreement", was signed in 1995 by the U.S. Navy, the State of Idaho, and the DOE. Basically, the Settlement Agreement permits DOE to receive shipments of spent nuclear fuel at the INEEL and establishes a required schedule for the treatment and removal of wastes from Idaho.

The specific sections of the Settlement Agreement that apply to SBW and calcine treatment and removal are:

1) Section E.5 - Calcination of SBW. This section requires complete calcination (i.e. treatment) of SBW by December 31, 2012. Calcination operations at INTEC have ceased and the New Waste Calcining Facility was placed in standby mode on June 1, 2000, however, DOE will still be required to comply with the treatment schedule for the SBW.

2) Section E.6 - Treatment of Calcined Wastes. This section requires that all HLW stored at the INEEL will be rendered road ready (immobilized) for transport to a suitable repository by the end of 2035 .

The immediate concern of the HLW Program was successful treatment of the remaining SBW currently stored in the INTEC Tank Farm Facility by the 2012 deadline. Subsequent development activities would concentrate on treatment of the inventory of calcined solids stored at INTEC.

\subsubsection{Program Requirements}

As previously discussed, the HLW Program was focused on processing SBW by direct vitrification. This process involves blending the liquid SBW with glass forming materials and/or glass frit. The resulting slurry is then transferred to a joule-heated melter where it is converted to a glass waste form.

A key SBW vitrification development activity would be verification and validation of preliminary laboratory research and development activities in a pilot-scale melter system. The pilot-scale melter system will provide the following capabilities:

1) Testing glass formulations to ensure products meet established requirements,

2) Defining off-gas compositions and contaminant removal efficiencies,

3) Testing of $\mathrm{NO}_{\mathrm{x}}$ abatement technologies,

4) Testing reductant effectiveness using additives such as sugar,

5) Developing off-gas sampling techniques and control schemes,

6) Developing measurement and control techniques for the reduction/oxidation state of the glass, 
7) Defining operating conditions and acceptable operating ranges for a Full-Scale Vitrification Facility,

8) Training for Full-Scale Vitrification Facility operators. The system will allow operators to gain experience operating a scaled joule-heated melter system that incorporates process equipment that is similar to that in the full-scale facility.

9) Training to allow vitrification facility systems engineers to become subject matter experts on joule-heated melter operation through the actual operation of melter systems. Effective hands-on training of both the facility operators and systems engineers will result in efficient and safe operation of the full-scale vitrification facility.

10) Continued development for vitrification of stored calcine.

11) Continued test bed support for investigation of any unusual operating scenarios observed in the full-scale facility.

Joule-heated melter technology has undergone extensive research and development at other government and private sector facilities. The HLW Program could utilize some of the existing and available equipment to verify/validate SBW direct vitrification flowsheets prior to full-scale facility design and operation. Successful operation of a full-scale vitrification facility will be largely dependent on the expertise of the personnel staffed to operate the facility. This expertise is best established by hands-on training through operation of pilot-scale systems.

\subsection{Assumptions}

1. This evaluation is for vitrification of simulated SBW only. Although the system may be invaluable in the development of a vitrification system for calcine, this evaluation is not within the scope of this report.

2. The variations in the costs associated with disassembly, transport, and re-assembly of the various systems are comparable, thus not differentiating. No cost analysis was performed as part of this evaluation.

3. The systems were evaluated exclusively as stand alone systems. Integrating specific components from various systems into a single melter system is beyond the scope of this report.

\subsection{Purpose}

The purpose of this report is to document the results of the evaluation process used to identify a joule-heated melter system that could be installed in the Idaho Falls area in support of the Direct Vitrification Development Program. Coordination with the DOE Tank Focus Area resulted in the identification of five melters or melter systems that could potentially support the direct vitrification development activities.

To evaluate these five systems, a set of key selection criteria was established. These criteria provide a basis for selecting a system that could be immediately transported to Idaho and assembled in a suitable facility to support the Direct Vitrification Development Program within the assumed budget and schedule. The key selection criteria include: 
1) Availability - The selected system should be immediately available in order to support installation of the system by January 1, 2002. Ownership by the DOE simplifies transfer to the INEEL.

2) Completeness of the system - Due to budget and schedule restrictions, redesign and work associated with major equipment additions or modifications must be minimized to the extent possible. This criterion was further broken down into urgent (immediate) and longer-term modifications required. Modifications were evaluated based on urgency, cost, and complexity.

3) Contamination - Budget and schedule restrictions do not allow for extensive radiological or chemical (Resource Conservation Recovery Act [RCRA] regulated) decontamination of the melter or auxiliary systems.

4) Scale - The selected system must be large enough to be scalable for process design, yet small enough to minimize the operating costs during development. To accomplish this balance, a melter with a relatively large surface area to volume ratio, (i.e. a shallow melt pool) is preferred, with a fairly small overall volume desirable. Melter residence time should approximate the Full-Scale Vitrification Facility.

5) Materials of construction - The flowsheet for SBW vitrification includes a feedstock that contains high nitric acid concentrations. Materials of construction must be compatible with the feed solution and offgas components must be compatible with high concentrations of $\mathrm{NO}_{\mathrm{x}}$ Therefore stainless steel feed and offgas system components and K-3 glass contact refractory in the melter is desirable.

6) Facility requirements - The size of the melter and supporting equipment will determine the facility requirements. Smaller footprint and lesser utility requirements are desirable.

7) Unique Features -Other parameters that distinguish a system, which can be positive or negative attributes.

8) To complete processing of SBW by January 1, 2013, a pilot-scale melter system should be installed by January 1, 2002.

9) A total budget of $\$ 1,000,000$ is available to select a melter system, disassemble and transport it to Idaho, and reassemble it in a suitable facility. 


\section{SYSTEM EVALUATIONS}

In a joule-heated melter system, wastes are typically fed to the melter in a slurry form to facilitate waste transfer into the system. Glass forming material or glass frit is mixed with the waste to provide the silica and fluxes needed to melt at the operating temperature. A key principle of successful vitrification of waste materials is to add the correct type and quantity of glass formers to enable successful formation of a glass waste form that meets performance requirements.

Consequently, operations involving feed batch blending and preparation are as important as actual melter operations. Feed batch analysis will be required to ensure feed compositions are within their defined ranges.

Joule-heated melters heat the glass by passing electric current through the molten glass. The electrical resistance of the glass results in the generation of heat in the melt pool. Key parameters to control during melter operations are the melter operating temperature, glass viscosity, and the overall reduction/oxidation state of the melt. These parameters must be maintained within operating ranges, as determined by development efforts, to minimize the potential for process upset conditions. The parameters that operators can quickly control are the melter operating temperature, the waste feed rate, and thus the melt rate. Operators must be sufficiently skilled to relate indirect observations to the possible onset of adverse melting conditions.

Table 1 summarizes how closely each of the five systems met the selection criteria. As shown, only the SVS-III melter system at West Valley met all of the key criteria.

\subsection{Scaled Vitrification System, West Valley Demonstration Project}

The Vitrification Facility (VF) at the West Valley Demonstration Project (WVDP) is designed to convert the high-level liquid radioactive waste stored on site to a stable glass for disposal at a federal repository. A series of tests were conducted between February and August, 1995 in the Scaled Vitrification System (SVS-III) to refine and optimize the process flowsheet. The SVS-III was built as a 1/7 scale model (based on surface area of the melt, 1/14 scale based on volume) of the full-scale VF. It has a melt pool volume of 62 liters, and a designed production rate of 4.5 to $12.0 \mathrm{~kg}$ of glass per hour under the WVDP flowsheet conditions (Jain et al. 2000).

The SVS-III is a joule-heated, slurry fed melter complete with a feed system and off-gas treatment system. Figure 1 shows a schematic of the SVS-III feed and melter system and Figure 2 shows a schematic of the SVS-III off-gas system. The numbered circles in Figures 1 and 2 represent process streams that are not defined in this report (Jain et al., 2000 defines the process streams and their respective flow rates).

The feed system consists of a 500 gallon Slurry Mix Tank (SMT), a 750 gallon Feed Hold Tank (FHT), and a 75 gallon Melter Feed Tank (MFT). All three tanks are constructed of $304 \mathrm{~L}$ stainless steel, and are equipped with mechanical agitators, ventilation lines, and transfer pumps. The SMT and FHT are jacketed tanks with internal heating and cooling coils, and both have level/density bubbler probes and liquid chemical addition lines. The SMT is fitted with a pneumatic transport system (PTS) for bulk dry chemical addition. The Vac-U-Max PTS feeds a solids separator tank, which is positioned directly above, and drains to the SMT. The transport air, which is moved via a 5-hp fan capable of delivering $200 \mathrm{cfm}$ of air, is filtered before discharge to the atmosphere. 


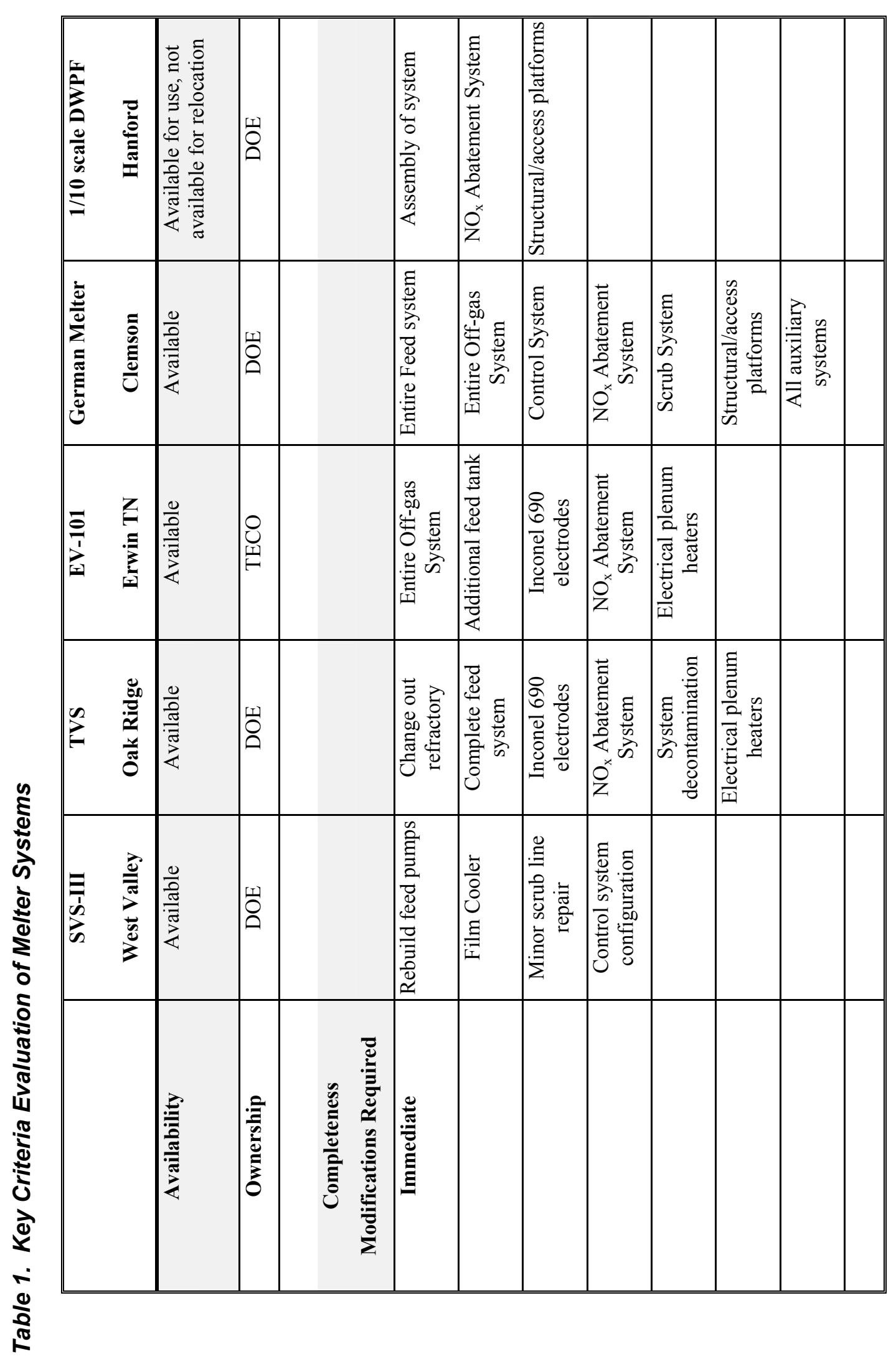




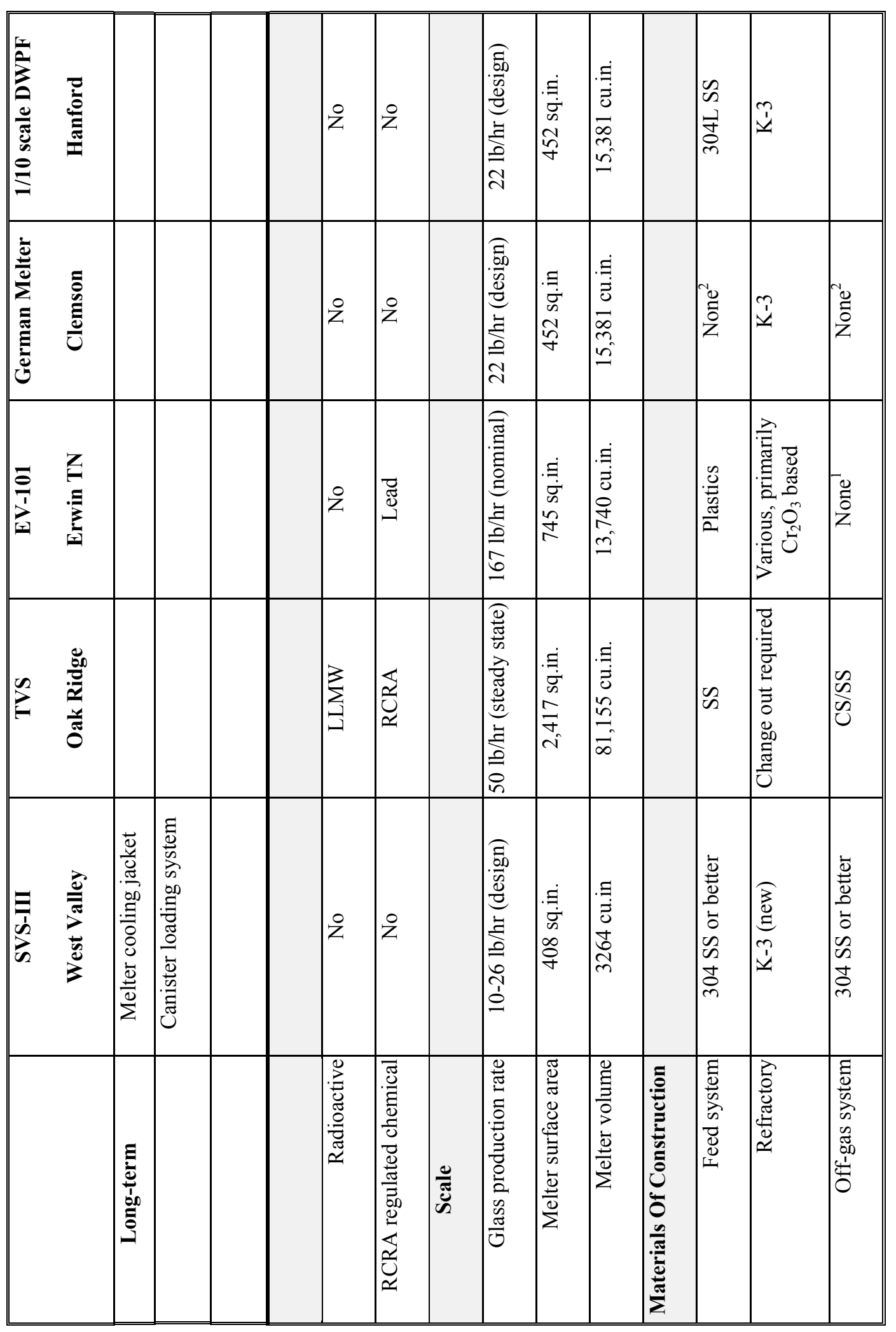




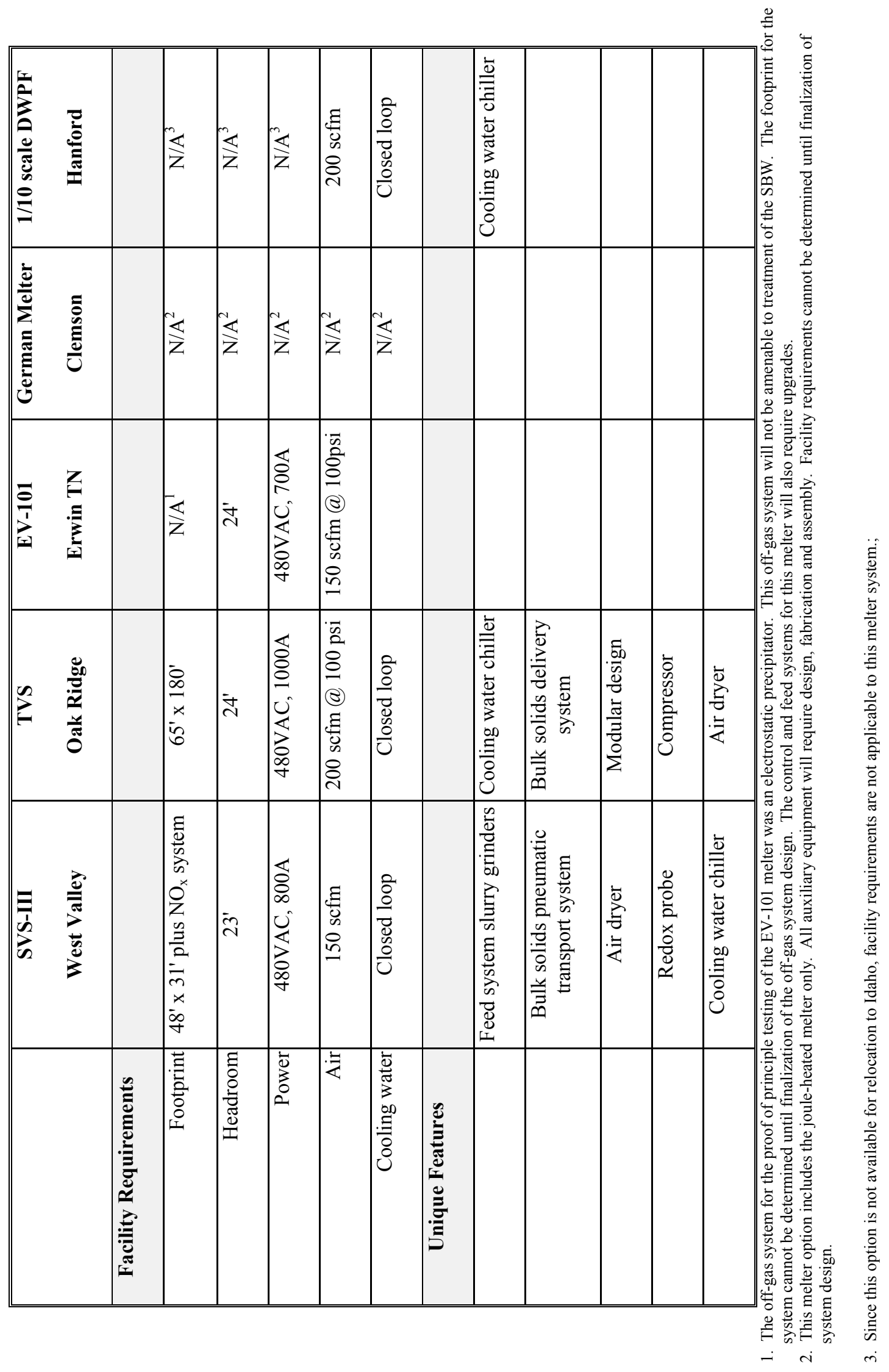




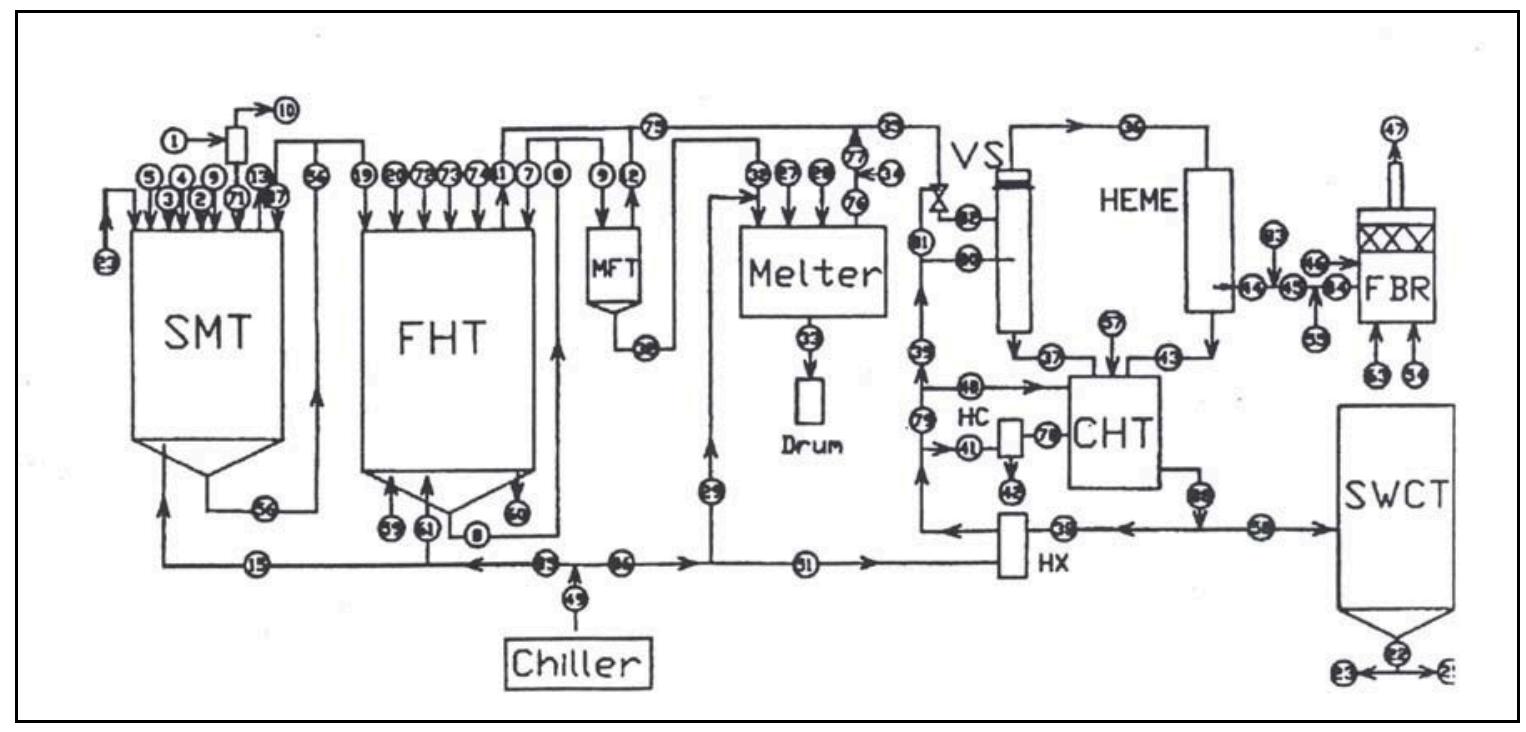

Figure 1: Schematic of SVS-III Feed System and Melter.

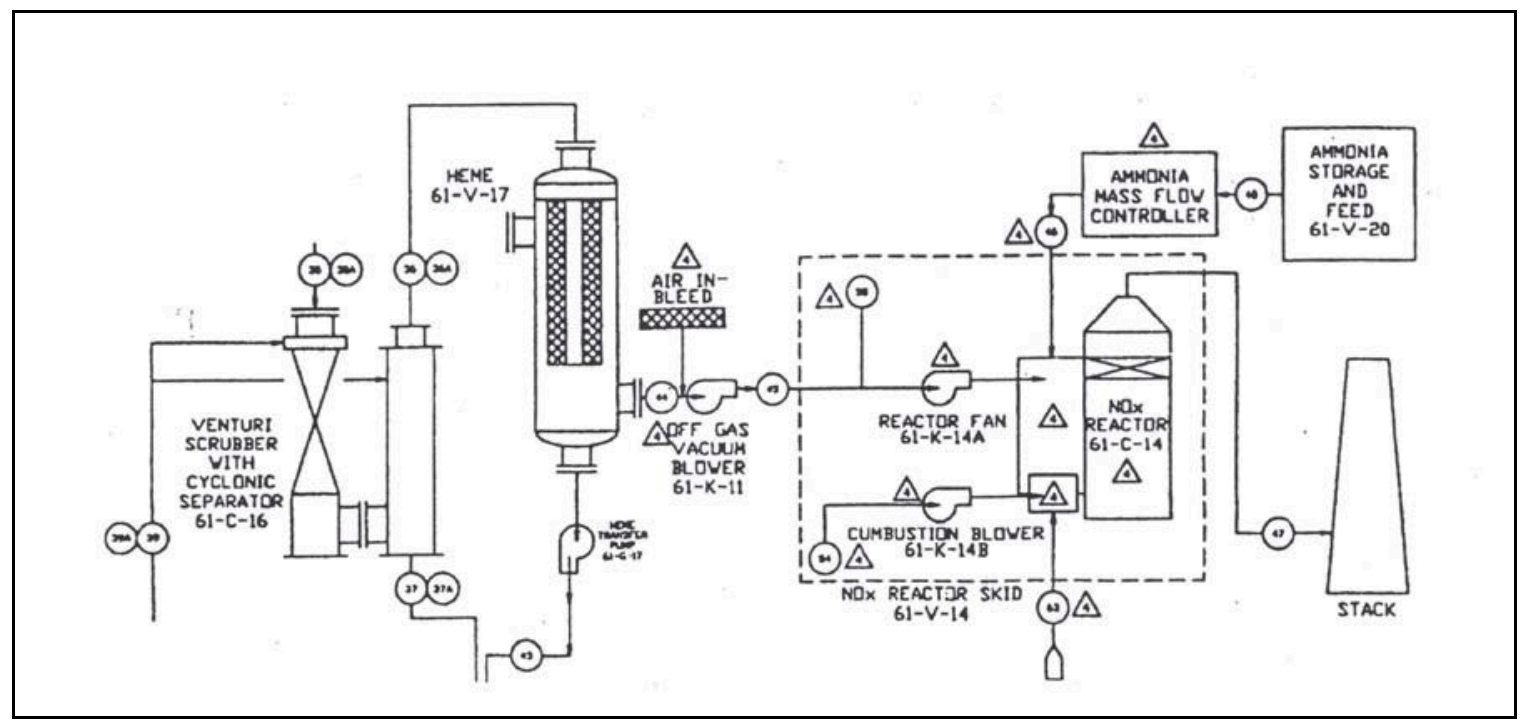

\section{Figure 2: Schematic of SVS-III Off-gas System.}

The off-gas treatment system consists of a venturi scrubber and a High Efficiency Mist Eliminator (HEME), supported by a scrub feed/collection system and a rotary lobe exhaust blower. The $\mathrm{NO}_{\mathrm{x}}$ abatement system uses ammonia as the reductant in a selective catalytic reduction system. The design flow rates for the various pieces of equipment range from 95 SCFM for the venturi, to 1200 SCFM for the HEME. The blower capacity is 145 SCFM.

The SVS-III melter, shown in Figure 3, is a rectangular shaped tank lined with Monofax K-3 refractory, straddled with a pair of paddle-shaped Inconel 690 electrodes. A single-phase silicon controlled rectifier (SCR) and transformer supply power to the electrodes via a programmable controller. The plenum contains four silicon-carbide resistance heaters inside Inconel sheaths. Power is supplied to each heater via a single phase SCR and transformer rated at $10 \mathrm{~kW}$. A 
double loop controller governs all four heaters. The melter has a water-cooled feed port, five view ports, and an emergency vent. It is not equipped with a sweep air/ film cooler system (although a design is available), nor is the melter shell cooled. The K-3/Zirmul refractory is new, as it was replaced after the last melter run.

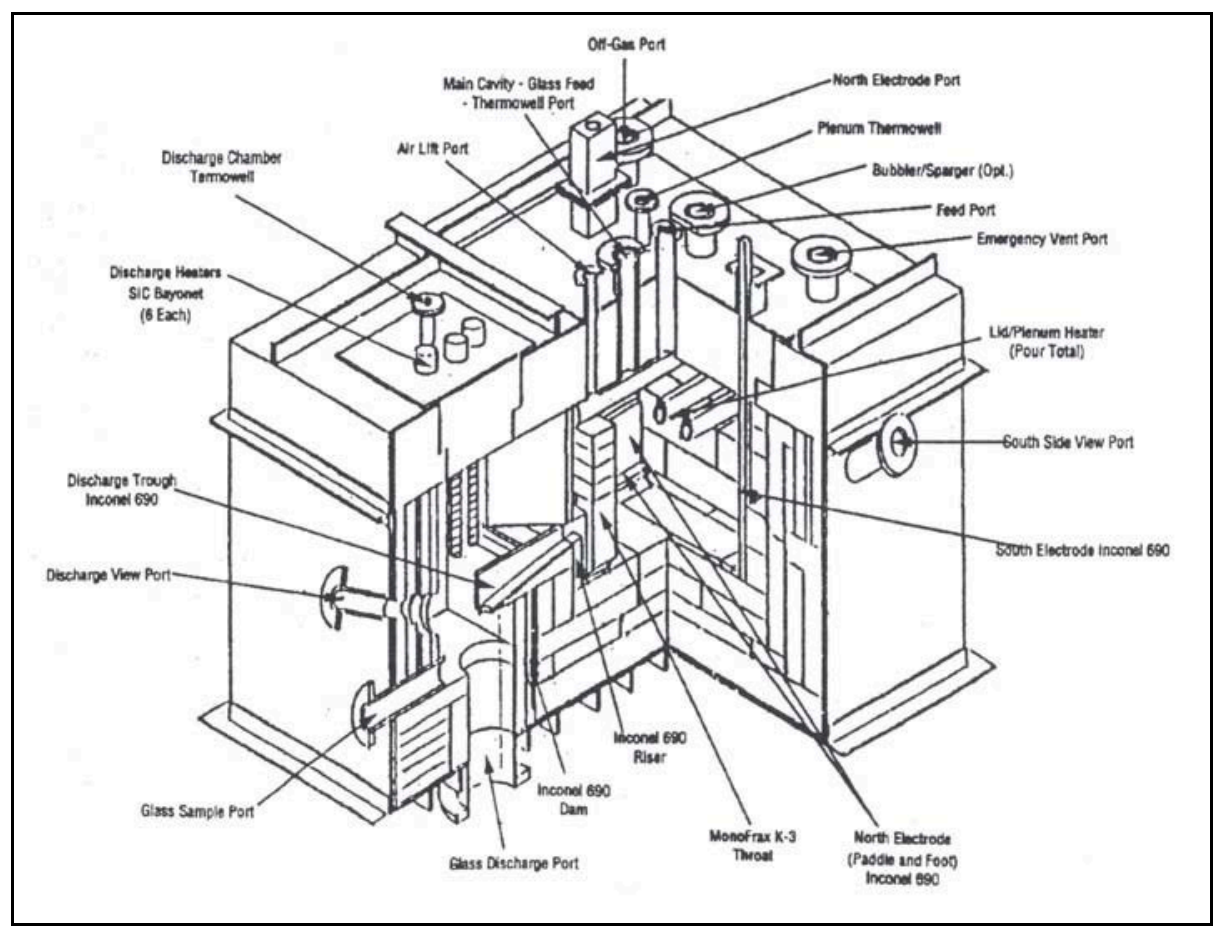

Figure 3: SVS-III Melter

Glass product is intermittently removed from the melter via an airlift at the riser, then flows through the Inconel 690 discharge trough to 30 gallon drums. The discharge trough is heated with six spiral cut silicon-carbide heaters rated at $8 \mathrm{~kW}$ each and powered by a single phase SCR and transformer.

As shown in Table 1, the SVS-III system has favorable attributes in all of the selection criteria on which this evaluation was based, and is the system recommended for deployment to Idaho. It is a complete system that closely represents the Full-Scale Vitrification Facility identified for the treatment of SBW at the INEEL (Quigley et al. 2000). It is scaled to provide a large surface area to volume ratio, which allows rapidly reaching steady state operation of the melter while minimizing the feed make-up and waste handling requirements of the development process. Glass residence time in the melter at slurry feed rates of $10-15 \mathrm{~L} / \mathrm{hr}$ would closely approximate the residence time provided in the conceptual full-scale SBW melter. The complete system, including the design documents, is the property of DOE, and it is available immediately for disposition. Complete operating histories, control loop diagrams, equipment lists and specifications, design drawings, instrumentation specifications, etc. are immediately available.

The system is constructed primarily of 304/304 L stainless steel, which is suitable for the flowsheet conditions expected during development operations. The K-3 refractory, which is preferred for high temperature operations, has been completely replaced. The Inconel 690 electrodes are in very good condition after minimal use and are similar to those identified in the 
feasibility study. The system was never used to process radioactive material, so none of the components are potentially radiologically contaminated.

Minor modifications would be needed for the system to fully support the SBW development program. A film cooler may be required to prevent the condensation of a glass film on the inner walls of the off-gas system components. The design of a film cooler has been completed and is available from WVDP. A cooling system for the melter shell may be needed if minor leaks form in the refractory. Minor repiping work will be required on the off-gas scrub system. Control system tuning may be required, since the control system was upgraded after testing was completed. A more elaborate canister loading system will be required if a proof of principle testing campaign is deemed necessary. Finally, alternative $\mathrm{NO}_{\mathrm{x}}$ abatement systems may have to be installed as off-gas conditions are further defined.

Overall, the SVS-III melter system will meet the immediate requirements for development of a direct vitrification process, and testing of the system could be initiated upon completion of the transport and installation of the system in an appropriate facility. Disassembly of the system, transporting it to Idaho, and re-assembly in a selected facility would be feasible within the proposed budget and schedule constraints.

\subsection{Transportable Vitrification System (TVS)}

In 1993, EM-50 sponsored a development effort to design and construct a deployable mixed waste vitrification system. The TVS was developed to demonstrate the technology and associated facility to vitrify an assortment of mixed waste sludges and solids which exist across the various DOE complex sites. The TVS, shown schematically in Figure 4, consists of four separate modules, which combine to form the complete system. These modules consist of the Waste and Additives Materials Processing Module, the Melter Module, the Emissions Control Module, and the Control and Services Module (MWFA 1998, Whitehouse et al.).

In the first module, waste and various glass forming additives are weighed, mixed and stored before their introduction to the melter. A 240-gallon melter feed blend tank equipped with load cells and an agitator is used to pre-blend the feed prior to transfer to the 300 -gallon melter feed tank. A centrifugal pump circulates the final feed mixture through a recirculation loop, from which a side stream is fed to the melter at rates up to $300 \mathrm{lb}$ per hour.

The melter module consists of a joule-heated glass melter equipped with molybdenum rod electrodes and lined with a "non-premium" heavy flux refractory. Slurried feed is fed to the top of the melter through a rotating nozzle, which distributes the feed over the melt surface to form a desired cold-cap. This cold cap, a melting batch layer covering the actual melt pool, serves to suppress the volatilization of waste components. The melter is equipped with both a drain bay chamber and a salt tap side chamber, where corrosive salts can be skimmed off the glass surface. Product glass is poured from the drain bay chamber into 8 cubic foot containers for interim storage.

Off-gas from all three main melter chambers enters the emission control module, where $99.99 \%$ of particulate less than 1 micron in diameter is removed. Two blowers control the flow of the offgas through the quench tower, packed bed cooler, variable throat venturi, mist eliminator, reheater, and HEPA filters. Scrub solutions are recirculated from the cooler and mist eliminator back to the quencher and venturi nozzles. Particle laden scrub is continually removed as blowdown. Sampling ports are provided at the discharge stack so emissions can be measured 
prior to discharge to the environment. The various off-gas components are designed for air flows ranging from 1000 to 1660 SCFM.

All of the TVS key parameters and equipment can be regulated, controlled, and monitored from the control and services module. A programmable logic controller coupled to a graphical user interface is run on an IBM compatible computer. This system controls melter operations, tracks and records key data, and calculates expected waste glass compositions based on feed rates and properties. This module also contains two $800 \mathrm{~A}, 480 \mathrm{~V}$, three phase electrical feeds for the power sources for the six melter zones.

Although the TVS is a complete, integrated vitrification system, several of the key selection criteria for a pilot-scale melter for SBW are not met, resulting in the elimination of the TVS from consideration for deployment to Idaho. The TVS has been used to process $\mathrm{B} \& \mathrm{C}$ pond sludge at Oak Ridge, and as a result, most of the components are radiologically contaminated. A complete and thorough decontamination effort, including replacement of the melter refractory and electrodes, would be required prior to deployment. An entire feed system would have to be designed and installed, as the available feed tanks are sized to provide approximately 3-4 hours of feed to the melter. The designed processing rate of $200-400 \mathrm{lb} / \mathrm{hr}$ of slurry feed is not applicable to a pilot-scale development system. The molybdenum rod type electrodes would have to be replaced with Inconel 690 plates to represent the system proposed for the Full-Scale Vitrification Facility. Similarly, the propane fired burner used to provide heat to the plenum would have to be replaced with electrical resistance heaters, and a transformer to power these heaters would have to be procured and installed. Finally, the TVS does not include any $\mathrm{NO}_{\mathrm{x}}$ abatement equipment which would be required to support melter operations.

\subsection{EV-101 Melter}

The Envitco WASTE-VIT EV-101 melter is owned by Toledo Engineering Company (TECO) and is currently in storage in Erwin, TN. It was last used to perform a proof of principal test in support of the Fernald Environmental Management Project OU-4 Silos Project (Bennert et al.). The system was run continuously for eight days, processing $7800 \mathrm{~kg}$ of feed, and generating 2952 $\mathrm{kg}$ of glass. The feed for this run was a non-radioactive surrogate which chemically and physically represented Fernald Silos 1 and 2 residue, described as a wet, gray, silty clay residue containing lead, barium, and arsenic. The feed waste loading for the demonstration was $83 \%$, with glass formers comprising the remaining $17 \%$.

The EV-101 melter is similar in design to the TVS. It consists of three chambers; the main melt chamber, the salt drain bay, and the glass drain chamber. It includes a propane burner in the main melt chamber plenum to provide the heat required to initially melt the glass bed to establish a conductive current path for joule-heating. Joule-heating is achieved via Molybdenum electrodes in the main melt and glass drain chambers. It is lined with alumino-silicate refractory encased in a water-cooled shell. It was designed for a nominal processing rate of 2 tons per day $(167 \mathrm{lb} / \mathrm{hr})$ of a typical soda-lime-silica (SLS) glass. 


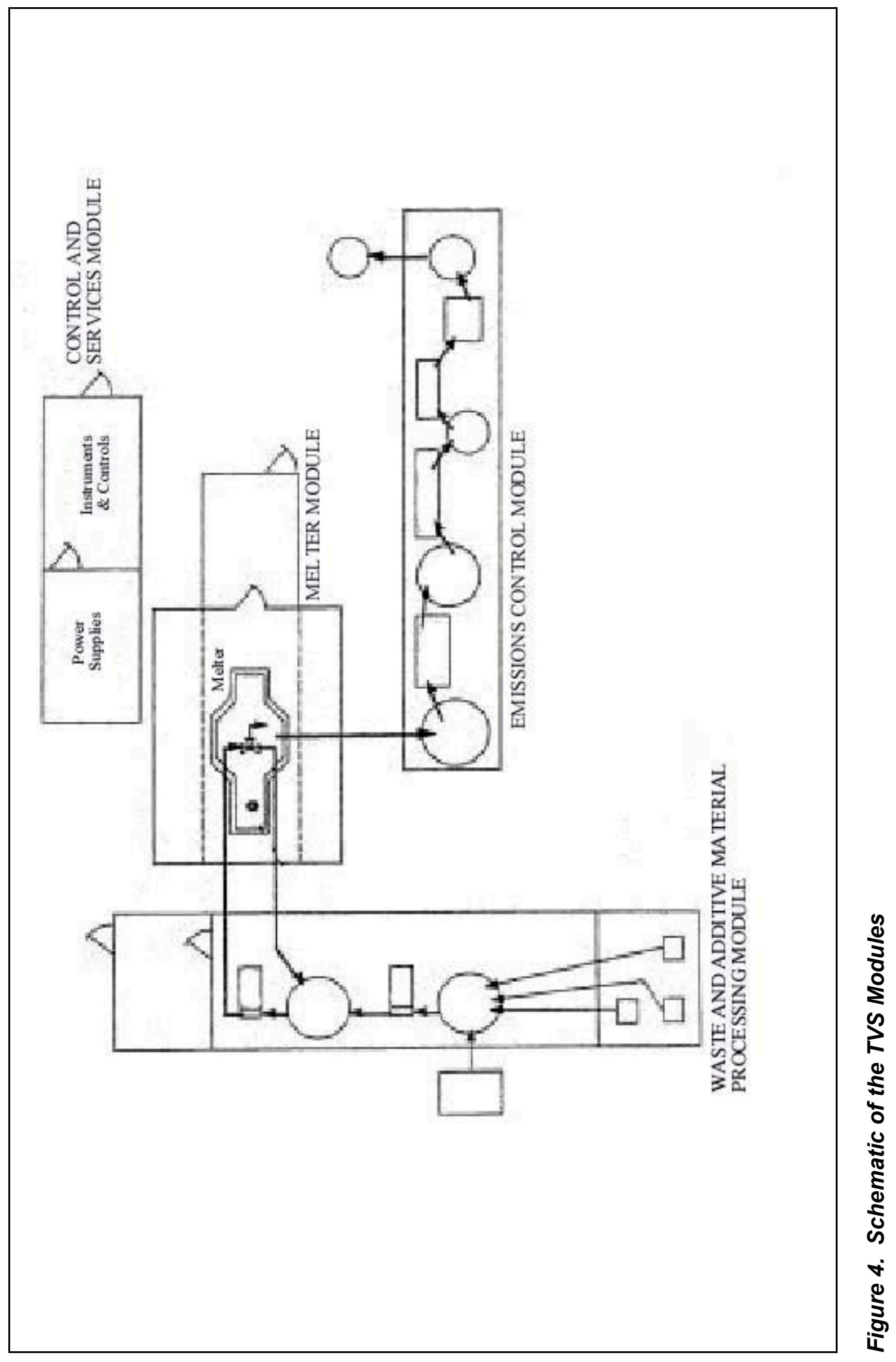


The feed system for the melter consists of a 600-gallon polyethylene/poly-propylene feed tank equipped with a mechanical agitator, two Moyno progressive cavity pumps and a magnetic flow meter. Any other required auxiliary equipment, including off-gas equipment, control and data acquisition systems, feed makeup equipment, and $\mathrm{NO}_{\mathrm{x}}$ abatement equipment are not included as part of this system.

The EV-101 does not meet most of the key selection criteria and is subsequently not recommended for selection. Major equipment systems (feed, control, off-gas, and $\mathrm{NO}_{\mathrm{x}}$ abatement systems) would have to be designed, procured, and installed to allow operation of this melter. Like the TVS, the electrodes and plenum burner would have to be replaced to represent the proposed Full-Scale Vitrification Facility. Finally, since the melter and design are proprietary, contract negotiations would be required to acquire this equipment. Constraints in the budget and schedule for the SBW development melter preclude further consideration of this melter.

\subsection{Tenth- scale Defense Waste Processing Facility Melter}

The Tenth-scale Defense Waste Processing Facility (DWPF) Melter was designed and built as a collaborative effort between Battelle and the KfK Institute as part of a Hanford Waste Vitrification Plant Program activity investigating the effects of noble metals on melter life. It has approximately $1 / 10$ the glass pool surface area of the DWPF HLW melter, with similar glass pool depth. The melter is complete, but has never been baked out, started, or operated. The feed and off-gas systems have been used to various degrees for other development activities (McCray \& Thomson 2001). Figure 5 is a diagram of a melter similar to the $1 / 10$ scale DWPF melter and the Engineering Scale Melter, discussed in Section 2.5 (Grunewald 1993).

Melter feed is prepared and staged in two, 500-gallon stainless steel, agitated feed tanks, from which it is pumped to the melter feed nozzle. The body of the melter is an Inconel shell lined with Alfrax refractory and a Monofrax K3 refractory liner. The melter shell is surrounded by a stainless steel cooling jacket. Glass discharge is induced by pressure differential through an Inconel riser and overflow tube, into a 30-gallon steel drum. The discharge section is heated with resistance heaters to maintain glass temperature. Two pairs of side entering Inconel 690 electrodes are used to supply heat to the melt pool. They are oriented in a top pair and bottom pair configuration. The plenum is equipped with two silicon-carbide heating elements in Hastelloy tubes. The melter has a bottom drain port that provides a method of draining the melter. Gases from the melter are treated by an off-gas treatment system consisting of a film cooler, ejector venturi scrubber, heat exchanger, and high efficiency mist eliminator.

Although the tenth-scale DWPF melter is a complete system that could be used to perform flow sheet verification/validation for SBW vitrification, it does not meet the key selection criterion that the system must be available for relocation to Idaho. It is not presently assembled at its current location at Pacific Northwest National Laboratory. Cost estimates to assemble the system in place are similar to estimates to assemble another system in Idaho. It does not include a $\mathrm{NO}_{\mathrm{x}}$ abatement system, which would require a delay to allow design, procurement, and installation. 


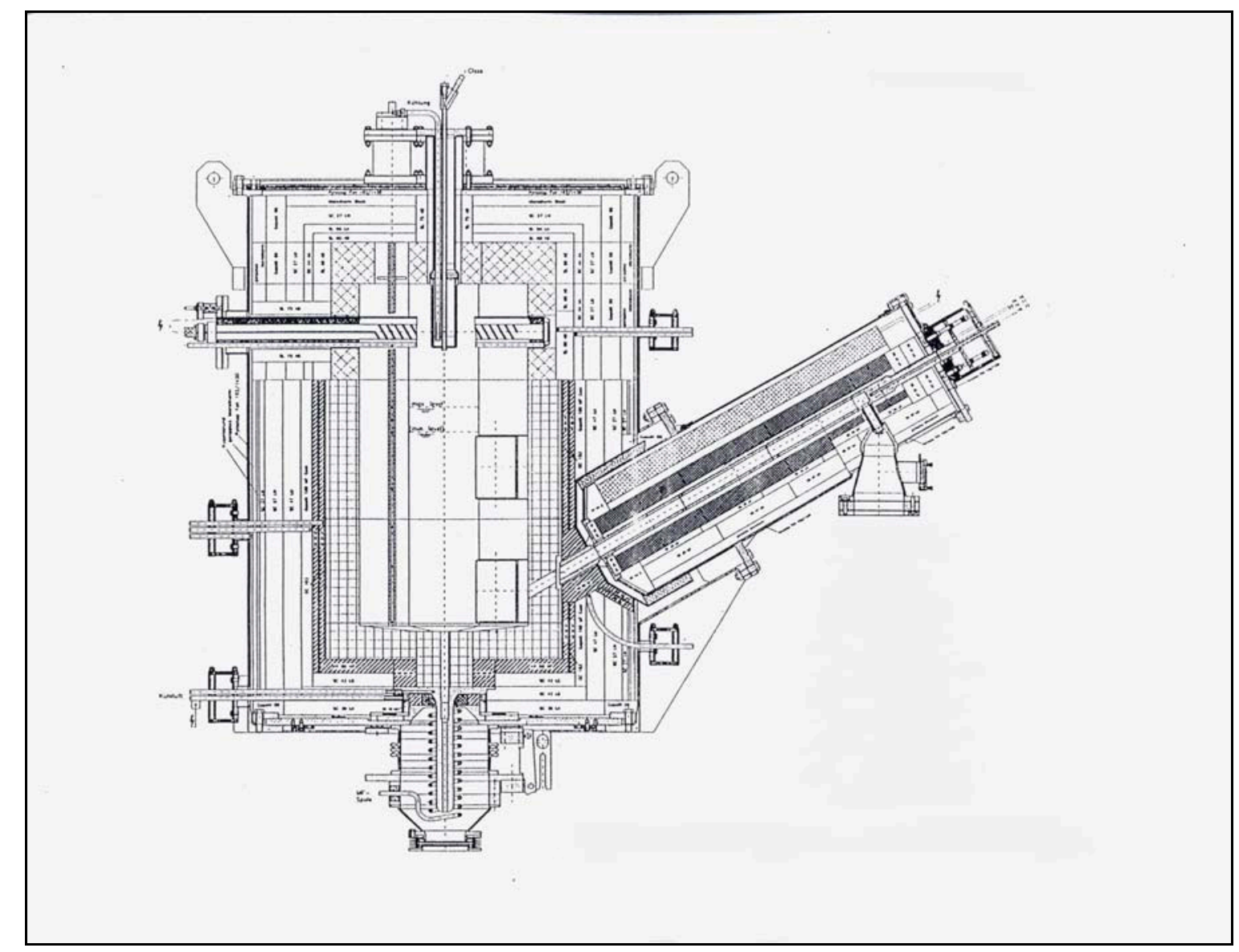

Figure 5: Melter similar to 1/10 scale DWPF and Engineering Scale Melter (Grunewald 1993)

\subsection{Engineering Scale (German) Melter}

The Engineering Scale Melter (ESM), located at the Clemson Engineering Technology Laboratory, is a slightly modified version of the 1/10 scale DWPF melter. The ESM does not include any of the required ancillary equipment, such as feed, off-gas, or control systems. The ESM is not recommended for relocation to Idaho because it consists only of the melter unit. All auxiliary systems, structural components, etc. would have to be designed, procured, and installed. All instrumentation, control loop configuration, and data collection requirements would need to be established. Budget and schedule constraints do not allow for this effort. 


\section{FACILITY REQUIREMENTS}

With the selection of the SVS-III as the preferred melter system for the Direct Vitrification Development Program, several factors will have to be considered to select a suitable facility to support its operation. Obvious requirements include a facility with adequate dimensions to accommodate the footprint of the melter system, the availability of required utility systems, operating permits, maintenance and operations support personnel, and proximity to the INEEL. Equally important considerations, especially for off-site facilities, include the existence of adequate environmental, safety, and health $(E S \& H)$, quality assurance, waste handling, procurement, training, and other programs which coincide with Bechtel BWXT Idaho, LLC's (BBWI's) commitment to DOE. Generally, contractors and their facilities that have successfully undergone a BBWI due diligence audit and are listed on the BBWI Qualified Suppliers List (QSL) should be considered as preferred off-site facilities.

The system footprint requires a minimum floor space of $48-\mathrm{ft}$ by $31-\mathrm{ft}$ with a minimum ceiling height of $23 \mathrm{ft}$. Additional space will be required for bulk material and product storage capabilities. In addition to this area, the $\mathrm{NO}_{\mathrm{x}}$ abatement skid, off-gas sampling and analysis trailer, and the ammonia storage shed would require an additional space of approximately $24-\mathrm{ft}$ by $24-\mathrm{ft}$. This additional equipment can be stored outside of the main facility, as this equipment is either designed for outdoor operation or contained within an enclosed trailer. A facility with a dedicated floor space of $50-\mathrm{ft} \times 70$-ft, with a 30 -foot ceiling would adequately house the entire system. The utility system requirements include:

- Electrical: 480VAC, 3-phase, 800 A Service

- Water: All cooling water is within a closed loop chiller system. Water is required for feed makeup, eyewashes, safety showers, fire protection system, and steam generator makeup.

- Air: $\quad 200$ scfm @ 100 psig.

- Fuel Oil (or propane): $\quad$ Required for existing SVS-III $\mathrm{NO}_{\mathrm{x}}$ abatement system.

- Steam: Steam generator included in SVS-III process equipment.

- Fire Protection system: In accordance with NFPA standards.

- Eyewash/Safety showers: As required per OSHA standards.

- Floor loading requirements: Subject to engineering analysis.

Several facilities exist, both on and off the INEEL site that would meet the space and utility requirements for housing the system. Advantages and disadvantages exist for each facility, and an internal evaluation would have to be performed to select a facility. On-site facilities that would meet, either as is or with minor modifications, all of the space and utility requirements, include, but are not limited to CPP-1634 at INTEC and the High Bay of TAN 607-A. However, other issues will have to be evaluated for each of these sites. These issues have the potential to be a major factor in the success of the development program, equally as critical as the research and development engineering effort. These issues include, but are not limited to:

1) The current use, work load, and availability of maintenance and operations personnel. 
2) The relative priority of the direct vitrification development milestones. How will competing priorities for the execution of other programs at the site/facility affect the allocation of resources for support for the Direct Vitrification Development Program?

3) Allocation of the facility infrastructure costs and overhead. What portion of facility modifications, repairs, and maintenance will be charged to the Direct Vitrification Development Program?

4) The availability of National Environmental Policy Act permits for the facility, and modifications required to accommodate operation of the melter system. What is the time frame for acquiring these permits?

5) The availability of a dedicated maintenance crew, versus a labor pool assigned regardless of their familiarity with the system.

6) The availability of all other support groups, including ES\&H, quality assurance, work order planning and scheduling, operations support, waste handling, and procurement personnel.

7) The acceptability of the site-specific requirements for processing work orders, procuring minor equipment, and availability of support personnel and their effects to the program schedule.

Many of these criteria could be affected significantly by locating on or off of the INEEL. Private contractors that are on BBWI's Qualified Suppliers List have ES\&H and quality assurance programs that comply with BBWI's established standards. A Solicitation of Interest and/or a Request for Proposal would have to be published in the Commerce Business Daily to determine the interest and technical qualifications of private sector companies. 


\section{CONCLUSIONS}

Establishing a pilot-scale melter system in Idaho would be a significant contribution to the successful design and operation of a full-scale vitrification facility. In addition to facilitating the verification/validation of the SBW flowsheet, it will allow the operators and systems engineers to develop an expertise in vitrification system operations through hands-on operation of the pilot facility. It will also provide a local test bed for operations support during Full-Scale Vitrification Facility operations.

The SVS-III system most closely meets the established selection criteria, and is the system that is most suitable for the Direct Vitrification Development Program.

- It has desirable qualities under all of the key selection criteria

- It has been fully tested as an integrated system under flowsheet conditions similar to those targeted for SBW surrogate testing.

- It will not require any decontamination efforts, and the refractory is new. System Operability testing of the system could be initiated immediately after transport and assembly in the selected facility.

- $\mathrm{NO}_{\mathrm{x}}$ abatement during initial testing would be accomplished with the existing selective catalytic reduction system, which is included. Future development of alternative $\mathrm{NO}_{\mathrm{x}}$ abatement systems would not require major modification to the off-gas system, but rather a relatively simple disconnect of the selective catalytic reduction system and tie-in to the new $\mathrm{NO}_{\mathrm{x}}$ abatement system.

- The feed preparation and delivery system is much more complete than any of the other candidate systems. It includes both liquid and dry bulk delivery systems to the makeup tank, in line grinders to prevent line plugging and pump damage due to transfer of large particles, and continuous recirculation loops to maintain homogeneity of the feed slurry.

An extensive internal evaluation of available facilities, both on-site and off-site, should be conducted to determine the location for assembling the system. The facility should have a dedicated floor space of 50-feet by 70-feet and a ceiling height of 25-30 feet to allow for assembly of the system in a configuration similar to its existing footprint, and to allow for bulk chemical and material storage. This evaluation should place a high priority on the support capability of the various sites, and the affect of delayed support on the overall execution of the development program. 


\section{REFERENCES}

DOE, 1995. United States Department of Energy, United States Navy, State of Idaho, "Spent Fuel Settlement Agreement", October.

J. Vienna et al, 1999a. "Glass Formulation for Idaho National Engineering and Environmental Laboratory Zirconia Calcine High-Activity Waste”, PNNL-12202, December.

J. Vienna et al, 1999b. "Glass Formulation Development for INEEL Sodium -Bearing Waste", PNNL-12234, July.

C. Musick et al, 2000. "Technical Status Report: Vitrification Technology Development Using INEEL Run 78 Pilot Plant Calcine”, INEEL/EXT-2000-00110, February.

P. Dirkmaat, 2000. U.S. Department of Energy, Letter to J. Valentine, BBWI, "Initiation of FY2001 HLW Work Scope (INTEC-WP-00-035)", September.

EPA, 2000. Code of Federal Regulations, 40CFR268.40, "Treatment Standards for Hazardous Wastes", United States Environmental Protection Agency.

V. Jain et al, 2000. Topical Report: "Scaled Vitrification System III (SVS III) Process Development and Laboratory Tests at the West Valley Demonstration Project", May 2000 DOE report DOE/NE/44139-78, Contract No. AC24-81NE44139

J. Quigley et al, 2000. "Feasibility Study for Vitrification of Sodium-Bearing Waste, 90\% Draft", INEEL/INT-2000-00952, July.

Mixed Waste Focus Area, 1998. U.S. Department of Energy, "Innovative Technology Summary Report, Transportable Vitrification System”, Office of Science and Technology, OST Reference \#222, September.

J. Whitehouse et al, "Transportable Vitrification System: Operational Experience Gained During Vitrification of Simulated Mixed Waste", Westinghouse Savannah River Company, DOE Contract Number: DE-AC09-89SR18035

D. Bennert et al, "Envitco Silos 1 and 2 Proof of Principle Test, Final Report", Envitco Inc., Document Number 98703 PR DMB LTR 1999050409000 Q, Fluor Daniel Fernald Subcontract No. $98 \mathrm{WO} 002240$

C. McCray / T. Thomson, 2001. Personal communication with J. Perez, Battelle, Pacific Northwest National Laboratory, Richland, WA, January.

W. Grunewald et al, 1993. Kernforschungszentrum Karlsruhe (KfK) Institut fur Nukleare Entsorgungstechnik (INE), Campaign Report, "Vitrification of Noble Metals Containing NCAW Simulant with an Engineering Scale Melter (ESM)", September. 